\title{
Effect of Strategic Positioning on Organizational Performance of Independent Power Producers in Rwanda: A Case Study of Selected IPPs
}

\author{
Aline Mukeshimana, Irechukwu Eugenia Nkechi, and Henry Ogoi Jefferson
}

\begin{abstract}
Purpose of this study was to investigate the effect of strategic positioning on organizational performance of Independent Power Producers in Rwanda with a case study of selected IPPs. Moreover, this study sought to determine the effects of differentiation strategy, costing and promotion strategy, perceived quality of service as well as pricing strategy on the performance of selected IPPs in Rwanda. The related literature review was discussed on the theoretical review on positioning theory, Industrial organizational theory, resource based theory and stakeholder theory; empirical review on done on differentiation positioning, costing and promotion, costing and promotion, perceived quality of service and pricing strategy. It highlighted conceptual framework of strategic positioning on organizational performance. This study implemented a descriptive research design and data was analyzed using inferential and descriptive statics technique. Primary data was collected using questionnaires from target population thirty respondents who were Board members, executive directors, senior management staff and project managers. A sample of 30 was determined using Yamane's formula where purposive sampling approach was used for the Board members, Executive directors, senior management staff and Project managers. A questionnaire was utilized to collect the vital data from the respondents; the questionnaires were physically administered to the board of members, Executive directors, senior management staff, and project managers. Data collected was analyzed through SPSS version 21. Data analyzed was reported using frequencies presented in tables, percentages, pie-charts and standard deviation. This study established that differentiation strategy, costing and promotion, perceived quality as well as pricing strategy had positive impact on the organizational performance of Independent Power Producers in Rwanda. It further recommended future researchers to take on more studies in the management aspect of such entities.
\end{abstract}

Index Terms-Organizational Performance, Strategy, Competitiveness, Profitability.

\section{INTRODUCTION}

The $21^{\text {st }}$ Century has seen firms competing in a complex and challenging environment due numerous factors arising from Globalization, recurring and uncertain changes to the evolving use of information technologies (De Nisi, Hitt \& Jackson, 2003). Thus, senior managers in the competitive and sluggish growth markets, which portray most of current trades, have been busy trying to achieve the desired performance; moreover, scholars and practitioners have presented major concerns on the sources of competitive

Published on September 04, 2019

Authors are with KIM University. (e-mail: rutaline1@gmail.com, irenkechi@gmail.com, henry.ogoi@gmail.com) advantage of such businesses. Most organizations develop the best tactics so that their market position is consolidated. Maintaining competitive position and applying the right strategies regularly ensure the firm's continued existence in the market as well as good performance results (Athiyaman, 2005). Many firms continuously find profitable strategies to differentiate themselves from competitors as competition intensifies.

Competitiveness is considered a multidimensional concept comprising of shareholder value, customer value and the ability of the firm to act and react in such ever changing and uncertain business environment. Each of these dimensions must be viewed in relation rather than in absolute terms. Smarta (2004) states that the new wave of liberalization and competitive business environment have pushed organizations to awaken from the stagnation to overhaul their thinking and put on new caps to re-assess the external and internal environment. The future of the businesses lays in organizations' acquiring new skills to develop strategic visions.

Many firms have adopted various strategies such as strategic alliances, diversification, mergers and acquisitions (Hax \& Majluf, 2006). Positioning holds a fundamental role as it brings together market analysis, competitive analysis and segment analysis to internal business analysis. The Independent Power Producers in Rwanda were not been left behind, they have also put in place a number of strategies to handle challenges arising from globalization and trade liberalization. In the competitive energy sector, positioning explains the consumers' perception on the good's or services' or firm's performance on precise traits as compared to the rivals. Thus, Independent Power Producers have to either reinforce or adjust clients' perception or image.

Strategy is a fundamental framework through which an organization can simultaneously facilitate to adapt to the changing environment while addressing its vital continuity. Strategy is the scope and direction of an organization over a long term; it further provides competitiveness to the organization through the structure of means within a challenging environment to meet the wants of markets and meet the shareholders' prospects (Hax \& Majluf, 2006). Mintzberg (1994) denotes that 'strategy 'has been used innumerous, the most known being; Strategy is a plan, a 'how', a means of moving from here to there; Strategy is a scheme in actions over time; for instance, a firm that frequently advertise very lavish goods has adopted a "high end" strategy; Strategy is position i.e. it reflects verdicts to bid specific goods or services in specific markets; Strategy 
is perspective, that is, vision and direction.

A managerial practice known as strategic positioning is used to create a firm's level of positioning strategy whose objective is to effectively differentiate a firm from its competitors (Chew, 2003). Hooley et al (2004) notes that positioning could happen at three different levels: the firm's level, goods or service level and brand level. A positioning tactic is an important element of the planning strategic marketing as a process; urges Kotler and Andresen (2006) additionally it is lined up with the firm's objectives, abilities of the internal resource and opportunities in the outside market. Strategic positioning focuses on the external from the organizational point of view, it more fully appreciates the competitive and market milieu in which the firm functions (Hooley et al., 2004).

Organizational performance includes the real output of a firm as measured alongside its envisioned objectives in terms of profits. Organizational performance is comprised of several undertakings that help in setting the objectives of the firm and track the advancement towards the target (Johnson et al. 2006). It is utilized to make alterations to successfully achieve objectives at maximum productivity level. Business executives and shareholders are mostly frustrated by the firm's performance. However, duties and responsibilities must be clearly defined and accomplished, for any business to succeed. It is imperative that a firm develops strategies that are designed around the skills that would improve the organizational performance.

According to Swanson (2000), the firm's performance is the valued productive yield of a scheme in the terms of goods or services. Firm's performance may be sub-divided into three groups: monetary performance (profit), internal non-monetary performance (productivity) and external nonmonetary performance (e.g., customer gratification). There are a various indicators used to analyze the firm's performance. The balanced scorecard suggests both qualitative and quantitative measures that recognize various stake holders' expectations and related to assessment of performance in choice of strategy. Consequently, performance associated with both to processes management and short term outputs (Johnson et al. 2006).

A decade ago, the GoR decided to engage the private sector in the bid reach the national electrification as was set out in the its 10 year strategic plan intended to alleviate poverty among other things. Engaging the private sector was an immediate solution to shortage in the power supply and the moment to individual consumers as well as the industries and this was the inception of IPPs. Currently, this being a new and young sub-sector requiring heavy investments while being very crucial to not only the shareholders but mostly to the national economy, the researcher to went deep analysis, through this research, to understand how these IPPs adopt various positioning strategies to improve their overall performance.

\section{Statement of the Problem}

Positioning is an influential instrument that permits an organization to build an image. The Independent Power Producers have seen augmented stress on the adoption of a culture which effectively executes strategic objectives. This emergent attention is brought about by the belief that complete strategies offer a significant basis of competitive advantage in the energy sector which involves high levels of communication between organizations and their clienteles either directly or indirectly. A robust marketing culture results into retaining clients, which in turn, produces higher return (Ries \&Trout, 2000).

In today's competitive environment, firms and IPPs in particular should develop strategies that station them in market supremacy and increase the overall performance, if they must become profitable. Strategic positioning was acknowledged as an essential instrument to challenge the competitive forces in the Independent power producing market atmosphere and also as an instrument of improving such firms' performance. The energy sector, in which the independent power producers are found, plays a vital role in the nation's economic development. In fact, in Rwanda, all other sectors depend on this sector and any kind of disruption affect almost all other economic sectors.

Several studies conducted on the influence of strategic positioning on organizational performance include Nyakondo (2010) who investigated the factors affecting banking industry to adopt strategic positioning on mobile banking. He found out that some banks had adopted mobile banking to a moderate extent with emphasis on the implementation of mobile banking as a method of strategic positioning as a source of revenue, image and to increase customer satisfaction.

In this context the researcher sought to assess how the recently introduced sector of IPPs, position themselves to improve their performance. This is mainly because such firms go through so many procedures to acquire all necessary permits, high capital acquisition in additional to being a highly regulated sector. Particularly, the biggest concern on very high capital injection at the beginning of the project, it was important that researcher understood how such heavy investments are gained back through various strategies of positioning which improve the overall organizational performance of such IPPs in Rwanda. Though the strategic positioning notion and its consequence on firm's performance have attracted substantial attention, there is inadequate empirical literature on its practice and influence on firm's performance in the Rwandan context. The study, therefore, sought to determine the effects of strategic positioning on the organizational performance of the independent power producers with specific reference to selected local Independent Power Producers.

\section{LITERATURE REVIEW}

The main purpose of positioning is to identify and take ownership of a solid buying basis which gives the buyer a real advantage. Positioning is a process with two ways, comprised of the identification of the brands 'rivals and their unique features (Kapferer, 2012). Hence; according to Christine Raisanen \& Ann-Charlotte Stenberg, 2011, positioning theory provides a framework for analyzing the changing aspects of micro-social relations as they are being negotiated in discussions. The Industrial Organization Theory specifically attributes competitiveness to the influence of factors in the industry or sector the firm belongs to (Grant, 1991) and specifically Porter's five-forces model 
plays a very important role in analyzing and explaining competitiveness in this perspective (Wills-Johnson, 2008). Furthermore, for a firm to attain continued success in the market place and maintain a competitive edge over its rivals (in other words strategic positioning), it has to be reinforced by the right set of greater resources and abilities (Strickland et al., 2012).

\section{Research Methodology}

\section{A. Research Design and Target Population}

This study adopted a descriptive quantitative research design. According to Coopers \& Schindler (2008), it is a systematic technique used to observe and describe the comportment of a matter without any influence. It was intended to obtain additional information on variables in a certain area of study. It is intended to use the image of a situation as it naturally occurs (Burns \& Grove, 2007). The objectives were indicated, and a clear definition of the population was given. For the effectiveness and efficiency required for descriptive studies, data collection tools have been assessed (Zikmund, Babin, Carr \& Griffin 2010). A target population is the entire group of all analytical units that a researcher wishes to consider for a specific study (Babbie, 2015). The target population of this research was the 32 top managers at the selected IPPS who hold the different positions in their respective companies. Respondents of the current study were strategic leaders; Board Members, Executive directors, senior managers and Project managers.

\section{B. Sample Size and Sampling Technique}

A sample size of 30 respondents was selected from a whole population of 32 persons with the help of a formula by Yamane (1967). Purposive sampling technique was used in selecting the Board Members, Executive Directors, senior managers as well as Project managers. Purposive sampling method was adopted to ensure that concerned groups of a population are effectively represented and accurate information is provided.

$$
n=\frac{N}{1+N(e)^{2}}
$$

This gave a sample of 30 respondents.

\section{Data Collection Methods}

The study used a questionnaire to collect data. A questionnaire is a data collection tool that involves a series of questions and other instructions aimed at collecting information from respondents (Brace, 2008). This study used a questionnaire because it was easy to distribute to the respondents. The questionnaire had both open and ended questions.

\section{1) Pilot Testing of the Instrument}

The questionnaire was administered to 3 staff, which is about $10 \%$ of the sample population for pre-testing. Pretesting provides room for inaccuracies to be detected prior to the actual data collection, and $10 \%$ of the sample size is considered adequate for testing (Mugenda \& Mugenda,
2003). After pilot testing the tool seemed accurate vis a vis the topic at hand. These respondents in the main study were exempted from the pilot to avoid prejudice due to foreknowledge.

\section{2) Validity of the Instrument}

Construct validity is used in this study to verify how the questions are formulated to make sure that convey the meaning and intent. In addition, content validity is used to verify that the questions are in line with the objectives. This ensures that the questionnaire demonstrate what is envisioned. Validity is the accurateness and significance of the assumptions based on the study findings. It is the extent to which the research findings extracted from the data analysis comprise the study variables, Mugenda \& Mugenda (1999). The questionnaire was given to other professionals including my supervisor to critique it and assure both content and concept rationality of the instrument.

\section{3) Reliability of Instrument}

The degree of consistency of the research results over time is reliable and the total population being studied is accurately represented (Golafshani, 2003). The objective of reliability scrutiny is to examine the extent to which a dimension procedure results in the same way, if there is reoccurrence of process as it was under the same conditions (Tokeetal, 2012). With the help of SPSS 21, the collected was tested for reliability

\section{Data Analysis Technique}

The collected data was coded and examined by use of SPSS (statistical package for social sciences) version 21. The data collected was then analyzed using both descriptive and inferential statistics in relation to the objectives of the study. The study was based on a multiple regression model. The analysis was based on dependent, independent and error term. The test and correlation study was carried out to determine whether there was significant relationship between the variables and to test whether the independent variables have a relationship.

A multiple regression model was used in this study is shown below:

$$
Y=\alpha+\beta_{1} X_{1}+\beta_{2} X_{2}+\beta_{3} X_{3}+\beta_{4} X_{4}+\varepsilon
$$

\section{RESEARCH FINDINGS AND DisCUSSIONS}

\section{A. Introduction}

This chapter comprises the findings, analysis as well as discussions on the information acquired from the respondents. The findings are presented in percentages and frequency distribution, mean and standard deviation as well as regression analysis. A total of 30 questionnaires distributed to four companies, namely Ngali Energy, BBOXX, Mobisol and Ignite Power, were all returned, rating the response at $100 \%$. Among the respondents, there were 53\% senior managers, 27\% Project Managers, whereas $10 \%$ were Board Members and Executive Directors each.

The study further found that $50 \%$ of respondents have 5 years or less in the energy sector; whereas $30 \%$ range from 5 to 10 years of experience and $10 \%$ have above 10 years of experience in the sector. 


\section{B. Positioning Strategy}

A well-positioned organization has higher chances of achieving the strategic goals in a seemingly effortless manner. Respondents were asked to indicate to what extent they were in agreement with statements rendering to strategic positioning in the questionnaire using a scale of 1 to 5 , with 5 being the greatest extent and 1 being the least extent of agreement.

\section{1) Differentiation Strategy}

The below table showed that companies introduced various advertisement campaigns or other sales promotions (mean 3.63), additional services (mean 4.06) and message of differentiation (mean 3.90) to differentiate themselves from their competitors. It was also noted that companies have created unique brand names compared to their competitors (mean 4.20) and they are swift to introducing new products or projects (mean 3.76). It was understood that companies use differentiation strategy to improve their performance to a greater extent (mean 3.91).

\section{TABLE I: DIFFERENTIATION STRATEGY}

\begin{tabular}{lccc}
\hline \hline $\begin{array}{l}\text { Description } \\
\begin{array}{l}\text { The company creates new advertising campaign } \\
\text { or other sales promotions }\end{array}\end{array}$ & 3.6333 & 1.35146 & 30 \\
\hline $\begin{array}{l}\text { The company introduces additional services e.g. } \\
\text { operations and maintenance }\end{array}$ & 4.0667 & 1.04826 & 30 \\
\hline $\begin{array}{l}\text { The company has a unique brand as compared to } \\
\text { the competitors }\end{array}$ & 4.2000 & .84690 & 30 \\
\hline $\begin{array}{l}\text { The company is swift in introducing new } \\
\text { products or new Projects }\end{array}$ & 3.7667 & 1.16511 & 30 \\
\hline $\begin{array}{l}\text { Message of differentiation reach the clients in } \\
\text { order to be effective }\end{array}$ & 3.9000 & .99481 & 30 \\
\hline \hline
\end{tabular}

\section{2) Costing and Promotion}

The below table revealed that IPPs used various costing and promotion strategies to improve the overall company performance. The outcome indicated that companies keep overhead cost lower (Mean 3.53) companies advertise their products and services (mean 3.63), they accept multiple forms of payment (mean 4.06) and that the companies design, produce and market their products in a more efficient manner (mean 4.20). Moreover, it found that the companies buy in bulk to reduce cost (mean 3.73) and that the companies benefit from the economies of scale (mean 3.66). It is, further, found that the companies are sensitive to the price of the products and still ensure growth in the industry (mean 3.96). It is found that respondents were neutral (mean 3.60) due to the fact that low costs permit the company to sell its products at the lowest competitive price and such low prices will gain competitive advantage and increase market share, due to price control and regulation done by the GoR through its regulatory authority (RURA). Generally, companies used this strategy to ensure continued growth of the companies (Mean 3.80).

TABLE II: COSTING AND PROMOTION

\begin{tabular}{lccc}
\hline \hline Description & Mean & $\begin{array}{c}\text { Std. } \\
\text { Deviation }\end{array}$ & $\mathrm{N}$ \\
\hline $\begin{array}{l}\text { The Company keeps overhead costs lower than } \\
\text { competitors }\end{array}$ & 3.5333 & .57135 & 30 \\
\hline $\begin{array}{l}\text { The Company accepts multiple forms of } \\
\text { payment }\end{array}$ & 4.0667 & 1.11211 & 30 \\
\hline Buys in bulk to reduce cost per unit & 3.7333 & 1.25762 & 30 \\
\hline \hline
\end{tabular}

\begin{tabular}{llll}
\hline \hline $\begin{array}{l}\text { The company advertises its products and } \\
\text { services }\end{array}$ & 3.6333 & 1.37674 & 30 \\
\hline $\begin{array}{l}\text { Low costs permit the company to sell its } \\
\text { products at the lowest competitive price and such } \\
\text { low prices will gain competitive advantage and } \\
\text { increase market share }\end{array}$ & 3.6000 & 1.13259 & 30 \\
$\begin{array}{l}\text { The company is sensitive to the price of the } \\
\text { product and still ensures growth in the industry }\end{array}$ & 3.9667 & .76489 & 30 \\
\hline $\begin{array}{l}\text { The company benefits from economics of scale } \\
\text { The company designs, produces, and markets its } \\
\text { product in a more efficient manner. }\end{array}$ & 4.6667 & 1.06134 & 30 \\
\hline \hline
\end{tabular}

\section{3) Perceived Quality of services}

The below table revealed that IPPs offer quality services that exceed customer expectations (mean 4.06), the companies offer reliable services to their customers (mean 4.53), they have the ability to convey trust to their customers (mean 4.30) and they have empathy on their customers (mean 4.26). It further established that companies individualized attention to the customers (mean 4.20), the companies present a realistic picture of their service to customers by checking the promotional messages for accuracy (mean 3.86), companies perform the service right to customers by stressing employees to provide reliable service (mean 4.4) and the companies effectively communicate with customers to ascertain their needs by using the service delivery process as an opportunity to impress on customers (mean 4.26).

\section{TABLE III: PERCEIVED QUALITY OF SERVICES}

\begin{tabular}{lccc}
\hline \hline Description & Mean & $\begin{array}{c}\text { Std. } \\
\text { Deviation }\end{array}$ & N \\
\hline $\begin{array}{l}\text { The company provides quality services that } \\
\text { exceed its customers' expectations }\end{array}$ & 4.0667 & 1.04826 & 30 \\
\hline $\begin{array}{l}\text { The company offers reliable services to its } \\
\text { customers }\end{array}$ & 4.5333 & .68145 & 30 \\
\hline $\begin{array}{l}\text { The company is responsive to its customers } \\
\text { (willingness to help customers and prompt }\end{array}$ & 4.3667 & .85029 & 30 \\
$\begin{array}{l}\text { service assurance) } \\
\begin{array}{l}\text { The company has the ability to convey trust to its } \\
\text { customers }\end{array}\end{array}$ & 4.3000 & .98786 & 30 \\
\hline $\begin{array}{l}\text { The company has empathy on its customers } \\
\text { The company offers individualized attention to } \\
\text { customers }\end{array}$ & 4.2667 & .90719 & 30 \\
\hline $\begin{array}{l}\text { The company present a realistic picture of their } \\
\text { service to customers by checking the } \\
\text { promotional messages for accuracy }\end{array}$ & 3.2000 & 1.12648 & 30 \\
\hline $\begin{array}{l}\text { Performing the service right to customers by } \\
\text { stressing employees to provide reliable service }\end{array}$ & 4.4000 & .67466 & 30 \\
\hline $\begin{array}{l}\text { The company effectively communicates with } \\
\text { customers to ascertain their needs by using the } \\
\text { service delivery process as an opportunity to } \\
\text { impress on customers }\end{array}$ & 4.2667 & .73968 & 30 \\
\hline \hline
\end{tabular}

\section{4) Pricing Strategy}

The table below indicated that pricing strategies adopted by the selected IPPs reflected the organizational goals (mean 4.00 ), that companies used efficient scale facilities (mean 3.90) and that prices were revised as the market forces change (mean 3.76). It was found that companies do not keep prices same as competitors (mean 2.7) due to price regulation done by the Government of Rwanda through RURA \& REG.

TABLE IV: PRICING STRATEGY

\begin{tabular}{lccc}
\hline \hline Description & Mean & $\begin{array}{c}\text { Std. } \\
\text { Deviation }\end{array}$ & N \\
\hline Pricing strategies reflect organizational goals & 4.0000 & 1.14470 & 30 \\
\hline \hline
\end{tabular}


The company uses efficient scale facilities

Prices are revised as market forces change

Keeps prices same as competitors

\section{5) Organizational Performance}

The table below indicated that companies competed for the consumers' attention and secure a recognizable comparative position in their minds in harmony with their cultural base (mean 4.13), that the companies compete for consumers' involvement in their daily operations (mean 4.13). It was established that companies have skills and resources to improve their competitive position (mean 4.43), that company has strong competitive position in the industry (mean 4.5) and does not shift its positioning frequently (mean 4.03). It was established that firms understand that positioning is the actual designing of company's image that helps customers understand and appreciate what the company stands for in relation to its competitors (mean 4.10).

TABLE V: ORGANIZATIONAL PERFORMANCE

\begin{tabular}{llccc}
\hline \hline Description & Mean & $\begin{array}{c}\text { Std. } \\
\text { Deviation }\end{array}$ & N \\
\hline $\begin{array}{l}\text { Our company compete for the consumers' } \\
\text { attention and secure a recognizable comparative } \\
\text { position in their minds in harmony with their } \\
\text { cultural base }\end{array}$ & 4.1333 & .89955 & 30 \\
$\begin{array}{l}\text { The company competes for consumers' } \\
\text { involvement in its daily operations }\end{array}$ & 4.1333 & .93710 & 30 \\
\hline $\begin{array}{l}\text { The company has skills and resources to improve } \\
\text { its competitive position }\end{array}$ & 4.4333 & .89763 & 30 \\
\hline $\begin{array}{l}\text { The company competes for the customers' effort } \\
\text { and time in the buying process }\end{array}$ & 3.9333 & 1.11211 & 30 \\
\hline $\begin{array}{l}\text { The company competes for the customers } \\
\text { 'willingness to deal with the technical }\end{array}$ & & & \\
$\begin{array}{l}\text { complexity found in the corresponding need for } \\
\text { services }\end{array}$ & 3.9333 & 1.08066 & 30 \\
\hline $\begin{array}{l}\text { The company competes for the funds consumers } \\
\text { are willing to spend in acquiring a service }\end{array}$ & 4.0333 & .96431 & 30 \\
\hline $\begin{array}{l}\text { The company does not shift its positioning } \\
\text { frequently }\end{array}$ & 4.0333 & .96431 & 30 \\
\hline $\begin{array}{l}\text { The company positioning is the actual designing } \\
\text { of company's image that helps customers } \\
\text { understand and appreciate what the company } \\
\text { stands for in relation to its competitors }\end{array}$ & 4.1000 & .71197 & 30 \\
\hline $\begin{array}{l}\text { The company has a strong competitive position } \\
\text { in the industry }\end{array}$ & 4.5000 & .73108 & 30 \\
\hline \hline
\end{tabular}

\section{Correlation Analysis}

This table below proved a positive correlation of variables. The level of correlation $(0.01)$ is statistically significant; this means that organization performance improves as positioning strategies are improved. It is evident that strategic positioning strategies have effects on organizational performance.

TABLE VI: CORRELATIONS ANALYSIS

\begin{tabular}{llcc}
\hline \hline \multirow{2}{*}{$\begin{array}{l}\text { Description } \\
\text { Strategic } \\
\text { positioning }\end{array}$} & \multicolumn{2}{l}{$\begin{array}{c}\text { Strategic } \\
\text { positioning }\end{array}$} & $\begin{array}{c}\text { Organizational } \\
\text { performance }\end{array}$ \\
\cline { 2 - 4 } & Sig. (2-tailed) & 1 & $.802^{* *}$ \\
\cline { 2 - 4 } $\begin{array}{l}\text { Organizational } \\
\text { performance }\end{array}$ & $\mathrm{N}$ & 30 & .000 \\
\cline { 2 - 4 } & Pearson Correlation & $.802^{* *}$ & 30 \\
\cline { 2 - 4 } & $\mathrm{N}$ & .000 & 1 \\
\hline \hline
\end{tabular}

** Correlation is significant at the 0.01 level (2-tailed).

\section{Analysis of Variance}

The table indicates that the regression model predicts the dependent variable significantly well. The F value, 15.343, proves that independent variables have effect on dependent variable. That is; differentiation strategy, costing and promotion strategy, perceived quality of services and pricing strategy have positive significance on Organizational Performance

TABLE VII: ANOVA

\begin{tabular}{llcrrrr}
\hline \hline \multirow{2}{*}{ Model } & $\begin{array}{c}\text { Sum of } \\
\text { Squares }\end{array}$ & df & $\begin{array}{c}\text { Mean } \\
\text { Square }\end{array}$ & F & Sig. \\
\hline \multirow{3}{*}{1} & Regression & 774.052 & 4 & 193.513 & 15.343 & $.000^{\mathrm{b}}$ \\
\cline { 2 - 7 } & Residual & 315.314 & 25 & 12.613 & & \\
\cline { 2 - 7 } & Total & 1089.367 & 29 & & & \\
\hline
\end{tabular}

a. Dependent Variable: Organizational performance

b. Predictors: (Constant), Pricing Strategy, Perceived Quality of service, costing and Promotion Strategy, Differentiation strategy

\section{E. Model Analysis}

The above findings indicate that the value of adjusted $\mathrm{R}^{2}$ is 0.664 , an indication that there was a variation of $66.3 \%$ on organizational performance due to changes in the positioning strategy which are differentiation strategy, Costing and Promotion Strategy, Perceived Quality of service and Pricing Strategy at 95\% confidence interval. This means that $66.3 \%$ changes in organizational performance could be explained by changes in differentiation strategies Costing and Promotion Strategies, Perceived Quality of service and/or Pricing Strategies. It was further; found that there is a high degree of correlation between the study variables as shown by 0.843 .

TABLE VIII: MODEL SUMMARY

\begin{tabular}{|c|c|c|}
\hline Model R & R Square & Adjusted R Square Std. Error of the Estimate \\
\hline $1.843^{\mathrm{a}}$ & .711 & $.664 \quad 3.55142$ \\
\hline
\end{tabular}

\section{F. Analysis of Coefficient}

It is established that, from the below table, the regression equation established was

$$
Y=-3.844-0.159 X_{1}+0.489 X_{2}+0.423 X_{3}+0.913 X_{4}
$$

It was, hence revealed that holding differentiation strategy, costing and Promotion Strategies, Perceived Quality of service and Pricing Strategies at a constant zero, organizational performance would be at -3.844 . Results in the below table revealed that differentiation strategy had a significant coefficient $(B=-0.159, p$-value $=0.567)$. This inferred that differentiation strategy had a negative (no statistically) significant effect on organizational performance Results on the below table revealed that Costing and Promotion strategy had a significant coefficient $(B=0.489, p$-value $=0.020)$. This suggested that organization Costing and Promotion strategy had a positive significant effect on organizational performance. This study is in line with Munene (2013) who opined that promotional activities are highly important in increasing sales of a firm. Schilke, Reimann and Thomas (2009) settle this finding on costing and agree that cost leadership and standardization strategies provide potential synergies and the ability to enhance organizational competitive performance. Results on the 
below table revealed that Perceived Quality of service had a significant coefficient $(B=0.423$, $p$-value $=0.002)$. This infers that organization Perceived Quality of service strategy had a positive significant effect on organizational performance. Yoshifumi, Sammogram and ManzumaNdaaba (2018) confirmed the same stating that there is a positive relationship between productivity, service quality and organizational performance. Results on the below table revealed that pricing strategy had a significant coefficient $(B=0.913$, $p$-value $=0.003)$. This denotes that organization pricing strategy had a positive significant effect on organizational performance. These findings are in agreement with the findings of Simon, Belstein \&Luby (2008) who found that Price interferes directly and in a short term over the profitability and cost effectiveness of a firm.

TABLE IX: COEFFICIENTS ANALYSIS

\begin{tabular}{|c|c|c|c|c|c|c|}
\hline \multirow{2}{*}{\multicolumn{2}{|c|}{ Model }} & \multicolumn{2}{|c|}{$\begin{array}{l}\text { Unstandardized } \\
\text { Coefficients }\end{array}$} & \multicolumn{2}{|c|}{$\begin{array}{l}\text { Standardized } \\
\text { Coefficients } \mathrm{t}\end{array}$} & \multirow[t]{2}{*}{ Sig. } \\
\hline & & $\mathrm{B}$ & Std. E & Beta & & \\
\hline \multirow{5}{*}{1} & (Constant) & -3.844 & 5.425 & & -.709 & .485 \\
\hline & $\begin{array}{l}\text { Differentiation } \\
\text { strategy }\end{array}$ & -.159 & .275 & -.104 & -.580 & .567 \\
\hline & $\begin{array}{l}\text { Costing and } \\
\text { Promotion Strategy }\end{array}$ & .489 & .198 & .389 & 2.474 & .020 \\
\hline & $\begin{array}{l}\text { Perceived Quality } \\
\text { of service }\end{array}$ & .423 & .124 & .435 & 3.398 & .002 \\
\hline & Pricing Strategy & .913 & .279 & .422 & 3.274 & .003 \\
\hline
\end{tabular}

\section{SUMmERY, CONCLUSIONS AND RECOMMENDATIONS}

\section{A. Summary of the findings}

This study sought to assess the effects of strategic positioning on organizational performance of Independent Power Producers in Rwanda. From the information posed to strategic leaders of the selected IPPs it is true that positioning has effect on organization performance to a greater extent. Respondents revealed that positioning provides a structure to build and coordinate element of marketing mix to implement the positioning strategy as they put in place right strategies, such as differentiation, to meeting the customers' expectations. Differentiation strategy was found to be very important for IPPs especially those operating on off grid. This is stressed by Mooney (2007), where he states that competitive advantage stems from a firm's ability to leverage its internal strengths to respond to external environmental opportunities while avoiding external threats and internal weaknesses.

Costing and promotion strategy was another important tactic that respondent have proved to be effective in ensuring improving organizational performance especially those IPPs operating off grid mode. Low cost strategies adopted included keeping overhead cost low, buying in bulk and benefits from economies of scale; such signifies low cost leadership. These findings are in agreement with Porter (1985) whose view shows that low cost leadership strategies enable an organization to develop standardized products in large volume at low cost, which give that organization a competitive edge over the competitors in the market.

On the other hand; promotional activities were a vital tool to increasing sales especially with the off grid IPPs as supported by most of the respondents.

This study reveals how firms ensure that customers receive quality services, ensure reliability of the offered services as well as individualized attention to customer needs; this is case for both on and off grid operators. Tax and Brown (1998) noted that firms that encourage customers to complain achieved higher profit consequently retaining their customers.

Any Pricing Strategy which do not reflect to the organizational goals is detrimental to it performance. The respondents were also in agreement with this view that pricing strategy reflects the organizational goals. However, due to price regulation by the GoR firms negotiate tariffs within a certain range below/beyond which they would not be allowed to operate. The results are in line with the findings of Kimes and Wirtz (2002) where a firm charge relatively lower price to its competitors, its overall performance is improved.

\section{B. Conclusion}

The regression results and overall findings of this study revealed that there is a positively significant relationship between strategic positioning and organisational performance. Through various positioning strategies such differentiation, costing and promotion, perceived quality of services as well as pricing strategy, IPPs' performances in Rwanda are able to improve. Even though some IPPs have signed the power purchase agreements which set obligation to the client (REG) to purchase whatever that is produced, such IPPs have not relaxed, they still strive to ensure that the client gets quality services whereby they are able to convey trust, ensuring reliability and improving the responsiveness to the customer wishes and concerns. As result of positioning strategies firms do not change their positioning frequently and they have strong competitive position in the industry. In spite of the uniqueness of this industry today, firms are able to compete and gain competitive advantages especially the IPPs operating on Off-grid mode, thus performing to meet the objectives of the shareholders.

\section{Recommendations}

The IPP sector was incubated about a decade ago in Rwanda and it is still growing to achieve the intended goal which is to support the GoR in producing electricity enough to support the socio-economic needs of the nation. Energy sector is highly profitable sector though requires highly expensive investments, it is imperative IPPs set right strategies to not only meet the clients' needs but to also high return on investments. Firms should grab all currently available opportunities but envisage or forecast when the demand diminish in comparison to supply, IPPs are encouraged to look beyond the current contracts or market and innovatively create new products to offer the Rwanda market and probably think beyond Rwandan borders. Positioning involves critical thinking of how to best compete in highly competitive market while acquiring the competitive advantages which in the end enhance the overall organizational performance; hence IPPs in general and particularly the strategists are out to creatively come up with other products and services to enhance the companies' positioning as well the overall performance. These may include operation and maintenance services, engineering services, provision of training services and trade partnership with the manufactures, to mention a few. 
It is imperative that policy makers, such as RURA, MININFRA consider the inputs of the private sector (IPPs) while set the energy sector short, mid and long-term strategies, especially on setting tariffs and other regulated aspects. In so doing the IPPs will be able to lower their cost of production and work towards a cost-reflective consumer tariff.

Finally, other private sector players should be encouraged to invest in spare parts manufacturing and other consumables locally. The unavailability of these hinders the sustainability of such big investment to both IPPs and the government utility company, when procured abroad it encourages the trade deficit to the national economy and mostly affects the timely intervention of break downs and there is no cost effectiveness in such situations.

\section{REFERENCES}

Akan, J. J., Hofer, C. W., and Boulton, W. R. (2006), "Toward a system for classifying business strategies" Academy of Management Review, 13.

Allen, R., Helms, M., Takada, M., and White, C., (2006), Andrews, K.R. (1971), The Concept of Corporate Strategy, Dow-Jones Irwin, Homewood, IL.

Arnott, D (2002), "Bases of financial services positioning", Manchester Business School, Manchester, unpublished PhD thesis.

ATC Consortium (2011), http://www.mfi-upgrading-initiative.org MFI upgrading and rating initiative of the development bank of Austria in East Africa.

Athiyaman, A. (1995). The interface of tourism and strategy research: an analysis. Tourism Management, 16 (6), 447-453.

Berry, L.L., and Parasuraman, A. (1992), Marketing Services: Competing through Quality, Free Press, New York, NY.

Chew, C. (2003). 'What factors influence the positioning strategies in Voluntary Non-profit Organizationstowards a Conceptual Framework', Local Governance, 29(4), pp.288-323.

DeNisi, A. S., Hitt, M. A., and Jackson, S. E. (2003).The Knowledge Based Approach to Sustainable Competitive Advantage. New York: Oxford University press.

Daft, R. L. \&Marcic, D. (2013). Management: The new workplace. SouthWestern; Cengage Learning: Australia.

Fahy, J., and Hooley, G. (2004). Sustainable competitive advantage in electronic business: Towards a contingency perspective on the resource-based view. Journal of Strategic Marketing, 10(4), 241-253.

Hooley, G., Saunders, J.A. and Piercy, N.F. (2004) Marketing Strategy and Competitive Positioning (3rd edn.).Prentice-Hall, Harlow.

Javalgi, R.G., and Moberg, C.R. (2007), "Service loyalty: implications for service Providers", Journal of Services Marketing, Vol. 11 No.3, pp.165-79.

Johnson, G., Richard, P. J., Devinney, T. M., and Yip, G. S., (2006), Measuring Organizational Performance: Towards Methodological Best Practice. Journal of Management, Vol 35, pp. 718-804.

Kettunen, J. (2006). Strategic planning of regional development in higher education, Baltic Journal of Management, 1(3), 259-269.

Kotler, P. and Andreasen, A.R. (2006) Strategic Marketing for Non-profit Organizations (5th edn.).Pearson Education/Prentice-Hall, Upper Saddle River, New Jersey.

Kotler, P. (2002), A framework for marketing management. New Jersey, Prentice Hall-Pearson Education International.

Lewis, B.R., and Soureli, M. (2006), "The antecedents of consumer loyalty in retail banking", Journal of Consumer Behavior, Vol. 5 pp.15-31.

Mintzberg, H. (1988), Structure In Fives: Designing Effective Organizations, Prentice-Hall, Englewood Cliffs, NJ.

Mukherjee, Bimal (2012), Crude Processing at KPRL, Petroleum Insight Magazine, 1 st Quarter Issue Jan - March 2012.

Parasuraman, A., Berry, L.L., Zeithaml, V.A. (1991), "Understanding customer expectations of service", Sloan Management Review, Vol. 39 pp.39-48

Peteraf, M. (1993). The cornerstones of competitive advantage: A resourcebased view. Strategic Management Journal, 14: 179-191.
Petrick, J. A., Scherer, R. F., Brodzinski, J. D., Quinn, J. F., and Ainina, M. F. (2009)

Global Leadership Skills and Reputational Capital: Intangible Resources for Sustainable Competitive Advantage. The Academy of Management Executive, 13 (1), 58-69.

Pike, S., and Ryan. (2004) Destination positioning analysis through a comparison of cognitive, affective, and conative perceptions.Journal of Travel Research, 42, 333-42.

Porter, M. E. (1991). Towards a dynamic theory of strategy.Strategic Management Journal, 12(Winter), 95-117.

Porter, M. (1985), Competitive advantage: creating and sustaining superior performance. New York: The Free Press.

Porter, M. (1980).CompetitiveStrategy.The Free Press, New York.

Rust, R., and Zahorik, A.J., (1996), "Customer satisfaction, customer retention and market share", Journal of Retailing, Vol. 69 pp.193-215.

Spanos, Y. E., and Lioukas, S. (2001). An examination into the causal logic of rent generation: Contrasting Porter's competitive strategy framework and the resource-based perspective. Strategic Management Journal, 22(10), 907-934.

Temporal, M.L (2005), "Segmentation and positioning in a basic industry", Industrial Marketing Management, Vol. 16 pp.9-18.

Varley, R. and rafiq, M. (2004), Principles of retail management.New York, Palgrave.

Harada, T., Sivanadan, S. \&Ndanusa, M.M.N, (2018). Effect of Productivity and Perceived Quality on Organizational Performance from Lean Management Practice Perspective. Research Journal of Business Management, (12) 1-9

Abdullahi, H.G.H.H. (2017). Influence of differentiation strategy on performance of hotels- the moderating role of environmental munificence. School of Business Management, University Utara Malaysia.

https://www.researchgate.net/publication/47399217_Positioning_Theory_a nd_Discourse_Analysis_Some_Tools_for_Social_Interaction_Analysi

http://www.mininfra.gov.rw/fileadmin/user_upload/infos/Final_ESSP.pdf https://statistics.laerd.com/spss-tutorials/linear-regression-using-spssstatistics.php

http://eujournal.org/index.php/esj/article/viewFile/2174/2059 